\title{
USING INPUT-OUTPUT ANALYSIS APPROACH TO IDENTIFY THE ROLE OF AGRICULTURAL SECTORS IN JAMBI ECONOMY
}

\author{
Fitri Yanuar, Amir Amri, Murdi Saad, Syafaruddin \\ Faculty of Economics and Business, University of Jambi, Indonesia \\ *E-mail: yanuarfirti@gmail.com
}

\begin{abstract}
This study aims to analyze the linkages of agriculture sector to other sectors of the economy of Jambi Province and also to know the multiplier output and export multiplier of the agricultural sector. The agricultural sector which in fact is the dominant sector in Jambi can not develop optimally due to lack of maximum use of existing resources, so can not meet the needs of the region. The results of this study indicate that the structure of demand and supply tends to fluctuate; the structure of trade output has the largest contribution followed by the oil, gas and geothermal mining sector. The largest structure of value added is from the oil, gas and geothermal mining sector and is followed by the trade sector. GDP according to the largest business sector is from the agricultural sector and shows an increasing trend. The biggest number of output multipliers is the rubber sector, sawmills and wood processing, and other goods industries. While the biggest income multipliers are from the palm oil sector, other goods industries and the beverage industry. The biggest linkages between backward sectors are the rubber sector, sawmill and wood processing industry, and other goods industries. The biggest future linkages are the oil, gas and geothermal refining industry, financial institution banks, and other food industries. The key sectors in the economy of Jambi Province during the 2007-2016 were other food industry sectors, industrial goods from rubber and plastic, electricity and drinking water and land transportation.
\end{abstract}

\section{KEY WORDS}

Input-output, forward and backward linkages, Jambi province, multiplier.

Indonesia is known as an agricultural country which means that the State relies on the agricultural sector both as a source of livelihood and as a support for development.The agricultural sector includes the food crops subsector, horticulture subsector, fisheries subsector, livestock subsector, and forestry subsector. Agriculture is one of the most dominant sectors in people's income in Indonesia because the majority of Indonesia's population works as farmers. But agricultural productivity is still far from expectations. One of the factors that causes a lack of agricultural productivity is human resources that are still low in processing agricultural land and its results. The majority of farmers in Indonesia still use manual systems in processing agricultural land. The role of the agricultural sector which includes food agriculture and horticulture, plantations, livestock and fisheries, in the economy of Jambi Province is still dominant. However, the productivity of the agricultural sector was the lowest compared to other sectors.

The success of agricultural development requires several conditions or pre conditions which for each region are different. Pre-conditions include technical, economic, socio-cultural and others.. The general equilibrium theory is a branch of economic theory. It seeks to explain the behavior of supply, demand and prices in the economy as a whole or a lot with several markets, by trying to prove that the balance of goods prices exists and that all prices at equilibrium, then general equilibrium, differ from partial equilibrium. The input-output table is a description in the form of a row and column matrix that describes the transactions of goods and services and the linkages between other sectors (BPS Jambi Province, 2017). Input-Output Analysis shows that in the overall economy there are interrelationships and interdependencies between sectors. The output of a sector is an input for other sectors and vice versa, so that in the end the interconnection will lead to a balance between revenues 
and supply in the economy as a whole. In the input-output model, a productive sector is identified with a production process or activity.

\section{METHODS OF RESEARCH}

The activity of an economic sector is inseparable from other economic sectors, so that a policy that is directly related to the sector will have an impact on the economy on a macro basis. Changes in one sector will affect other sectors. The role of the agricultural sector in Jambi Province was analyzed using input-output analysis. Backward and forward linkage analysis is used to determine the structure of the agricultural sector so that in the end it can be determined which sub-sector is the key sector in the agricultural sector. This research aggregates other sectors in the economy besides the agricultural sector, so that it can still be seen the influence of the agricultural sector on the economy as a whole.

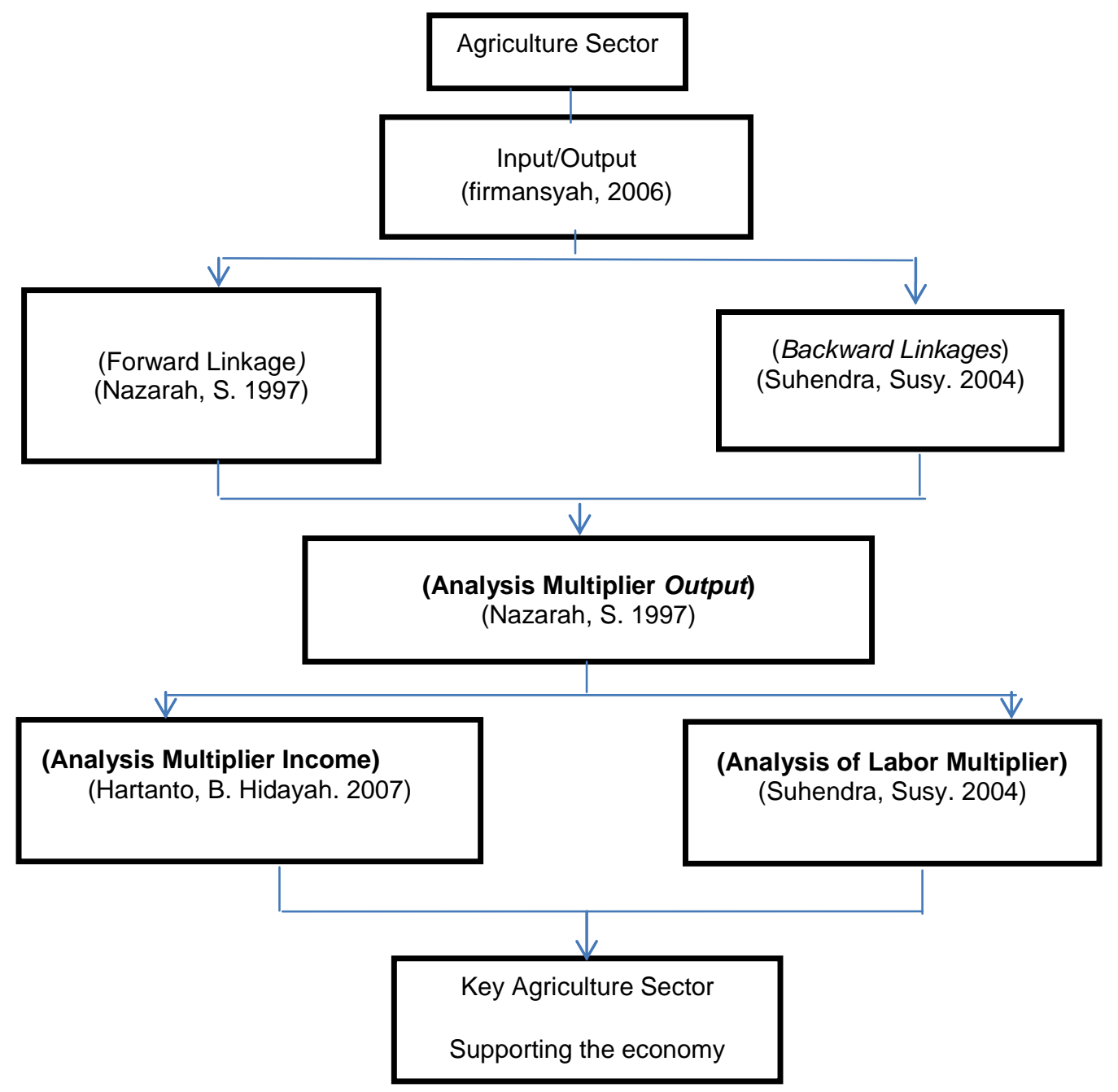

Figure 1 - Framework of Study

Analysis Methods and Sources. Data in this studyusing Jambi Province GRDP, Jambi Province in Figures and the last using Jambi Province Input-Output Table 2008 - 2016. In this study data collection using the documentation method or technology coefficient like a comparison between the number of sector outputs i used in sector $\mathrm{j}$ (Xij) with the total input of sector $\mathrm{j}(\mathrm{Xj})$. This coefficient can be translated as the number of inputs from sector $\mathrm{i}$ which is in one sector output unit j. Systematically can be written (Mauludin, Dudi):

$$
A i j=\frac{X I J}{X I}
$$


The matrix can be arranged as follows:

$$
\begin{gathered}
\text { a11 X1 +a12 X2 }+\ldots \ldots \ldots \ldots+{ }_{a 1 n} X_{n}+F_{1}=X_{1} \\
\text { a21 X1 +a22 X2 }+\ldots \ldots \ldots \ldots+{ }_{a 1 n} X_{n}+F_{2}=X_{2} \\
\text { an1 X1 +an2 X2 }+\ldots \ldots \ldots \ldots+\text { ann } X n+F n=X n
\end{gathered}
$$

If there have a change in the final demand, there will be a change in the national income policy. If written in the form of an equation, eating can be written as follows:

$$
A X+F=X \text { atau } F=X-A X N=(I-A)^{-1} F
$$

Where: $\mathrm{I}=$ Identity matrices measuring $\mathrm{n} \times \mathrm{n}$ whose elements contain numbers one on the diagonals and zeros; $F=$ Final request; $X=$ Output; $(I-A)=$ Leontief Matrix; $(I-A)-1=$ Leontief Reverse Matrix.

Linkage analysis between sectors are divided into backward linkages and forward likages. The backward link is an analysis to determine the degree of relevance of a sector to other sectors that contribute input to it. The future link is an analytical tool to find out the degree of linkages between a sector that produces output, to be used as input for other sectors (Kuncoro, Mudrajat; 2001), stated as follows:

$$
\operatorname{Lbj}=\frac{\sum_{i-j} X i j}{X j}=\sum_{i-j} a i j
$$

Where: Lbj - Backward linkage index; Xj - product valueto-j; Xij - Input value "i" provided for producing "j"; ij - input-output Leontief Coefficient.

The coefficient shown by Lbj as the effect level of backward linkages (backward linkages) if $>1$ indicates that one unit of the final demand of the sector will create a change above the average for overall economic activity. The second type of linkage between sectors in the economy is forward linkage. Future linkages are obtained from inverse backward links, mathematical formulations namely: (Kuncoro, Mudrajad; 2001).

$$
\mathrm{Lt}=\mathrm{j} \sum a i j-1
$$

Meanwhile in the calculation of future linkages, the Rassmusen method is also called the method of calculating sensitivity levels. Using the Rassmusen method the distribution power coefficient can be formulated as follows.

$$
\alpha \mathbf{j}=\frac{\sum_{t-1}^{n} b i j}{\frac{1}{n} \sum_{t-1}^{n} \sum_{t-1}^{n} b i j}
$$

Where: $a j$ - power distribution coefficient; bij - the matrix element is the inverse of row $\mathrm{i}$ column to j; $n$ - many matrix sectors.

Criteria:

a. if $\alpha \mathrm{j}=1$, the backward link between the $\mathrm{J}$ sector is the same as the average linkage behind all economic sectors.

b. if $\alpha j<1$, the backward link of the $j$ sector is lower than the average linkage behind all economic sectors.

c. if $\alpha j>1$, the backward linkage of the $j$ sector is above the linkage average behind all economic sectors. Or the jth sector has a high influence from other sectors.

The degree of sensitivity shows how much influence on the calculation of the future linkages is formulated with:

$$
\beta \mathrm{i}=\frac{\sum_{t-1}^{n} b i j}{\frac{1}{n} \sum_{t-1}^{n} \sum_{t-1}^{n} b i j}
$$


Where: $\beta \mathrm{i}$ - coefficient of degree of sensitivity; bij - The matrix element from row i column to j; $\mathrm{n}$ - many matrix sectors.

Criteria:

a. if $\beta i=1$ the future linkages of the second sector are the same as the average linkages in the future of all economic sectors.

b. if $\beta i<1$ the future linkages of the I sector are lower than the average linkages in the future of all economic sectors.

c. if $\beta i>1$ the future linkages of the $i$ sector are above the average linkages in the future of all economic sectors. Or the second sector has the highest influence from other sectors.

The coefficient shown by $i$ as the influence of the level of forward linkages if $>1$ means that the sensitivity level of sector $i$ is relatively higher than other sectors that have $i<1$, namely the demand for production in other sectors is very influential in the growth of the sector $i$. A sector if the value coefficient is $>1$ and i i 1 , then the sector is a key sector or it can be said as the leading sector in the economy in the region concerned, because it has a high level of forward linkages and backward linkages. The output multiplier number of a sector $\mathrm{j}$ is the total value of the output produced by the economy to meet (or as a result) a change in one unit of the final demand of the sector. The output multiplier is the number of columns of the Leontief inverse matrix element. By notation, formulated as:

$$
\text { Oij }=\sum \text { iaij }
$$

Where: $\mathrm{I}=1,2, \ldots ., \mathrm{n}$; $\alpha \mathrm{ij}=$ Leontief inverse matrix element; Oij = the output multiplier number j and_ij are matrix elements.

The multiplier of household income of a sector shows the change in the amount of income received by the household created due to the addition of one unit of money to the final demand for a sector. Household income multiplier matrix:

$$
\mathrm{Hi}=\mathrm{HR} . \mathrm{Oj}
$$

Where: HR = row vector $n+1$, because the nth row belongs to the transaction matrix and input coefficient; $H_{R}=\left[a_{n}+1,1 a_{n}+1,2 \ldots . . a_{n}+1_{n}\right]$.

$$
\frac{X n+1 j}{X j}
$$

Where: $\mathrm{Xn}+1 \mathrm{j}$ on the formula is the same as row $\mathrm{v}$ (primary input) for each sector.

The multiplier of the household income becomes:

$$
H j=\sum_{i-1}^{n} a n+1 j
$$

\section{RESULTS AND DISCUSSION}

The percentage of final requests tends to fluctuate. Final demand increased from 50.58 percent in 2007 to 52.79 percent in 2014 but declined again in 2016. Demand by domestic end consumers consisted of household and non-profit consumption, government consumption, capital formation and stock changes. The demand for goods and services by other production sectors in the context of production activities (intermediate demand) only reaches 25 percent of total demand, Table 1.

Viewed from the supply side, the goods and services needed to fulfill the demand come from domestic production, outside Jambi Province or even from abroad (import). The tendency of declining imports on the supply side is in line with the continued increase in the supply of domestic production goods and services. Dependence on imported goods began to decrease from 17.21 percent in 2007 to 9.8 percent in 2014 and again increased in 2016 to 
20.77. Meanwhile more than 90 percent of the supply of goods and services comes from own production.

Table 1 - Year Requests and Offers 2007, 2014 and2016 (\%)

\begin{tabular}{|c|ccc|cc|}
\hline \multirow{2}{*}{ Year } & \multicolumn{3}{|c|}{ Demand } & \multicolumn{2}{c|}{ Supply } \\
\cline { 2 - 6 } & between & Last & Export & Production & Import \\
\hline 2007 & 22,02 & 50,85 & 27,13 & 82,79 & 17,21 \\
2014 & 24,74 & 52,79 & 22,47 & 90,20 & 9,80 \\
2016 & 23,21 & 44,71 & 32,08 & 79,23 & 20,77 \\
\hline average & 23,32 & 49,45 & 27,22 & 84,07 & 15,92 \\
\hline
\end{tabular}

The output created from the production process as a sector within the framework of the Jambi provincial 10 model utilizes the availability of primary inputs and intermediate inputs, Table 2.

Table 2 - Output Structure of Jambi Province Year 2014 and 2016

\begin{tabular}{|c|c|c|c|}
\hline \multirow{2}{*}{ No } & \multirow{2}{*}{ Sector } & \multicolumn{2}{|c|}{ Contribution (\%) } \\
\hline & & 2014 & 2016 \\
\hline 1 & (43) trade & 12,97 & 13,38 \\
\hline 2 & (23) mining of oil, gas and geothermal & 86,86 & 9,09 \\
\hline 3 & (10) rubber & 6,91 & 11,01 \\
\hline 4 & (44) Hotels dan restaurants & 6,53 & - \\
\hline 5 & (51) Banks and financial institutions & 5,85 & - \\
\hline 6 & (42) Buildings & 4,44 & 5,67 \\
\hline 7 & (54) goverment and defense & 3,54 & 3,33 \\
\hline 8 & (12) palm oil & 3,49 & 5,57 \\
\hline 9 & (53) rent, real estate and company services & 3,20 & - \\
\hline 10 & (45) land transportation & 2,81 & - \\
\hline 11 & (24) non oil and gas mining and excavation & - & 3,05 \\
\hline 12 & (55) community social services & - & 4,37 \\
\hline 13 & (14) cinnamon & - & 3,72 \\
\hline 14 & (50) communication & - & 3,69 \\
\hline - & $\begin{array}{l}\text { Sub Total } \\
\text { Others }\end{array}$ & $\begin{array}{l}58,61 \\
41,39\end{array}$ & $\begin{array}{l}63,30 \\
36,70\end{array}$ \\
\hline
\end{tabular}

More than 50 percent of Jambi Province's total economic output is contributed by less than 10 main sectors. In 2014 the main sectors that dominated the creation of economic output in Jambi Province included: Trade (43), Oil, gas and geothermal (23) and Rubber (10). The ten main sectors in this period contributed 58.61 percent to the overall output, where the service sectors (tertiary) began to appear to dominate.

The production process in 2016 shows changes in the ten main sectors that dominate the economic output creation of Jambi Province. Changes that have taken place include the strengthening role of the oil, gas and geothermal sector and the sector of banks and financial institutions and the emergence of the palm oil sector as an impact of the expansion of large plantation companies. The decline in forest production and the prohibition of illegal logging has resulted in a decline in the plywood industry and the like. In this period ten main sectors contributed 63.30 percent to total output, and were more colored by agriculture and service.

The added value generated by the economic performance of Jambi Province in 2014 was mainly created by oil, gas and geothermal mining margins of 12.18 percent. The transportation margin that produces added value in the land transportation sector is also included in the ten main sectors, Table 3.

Along with the increase in production output, the role of oil, gas and geothermal mining in the formation of GRDP has also increased. The distribution of value added creation has not changed much, ten main sectors still control almost 60 percent of the GRDP structure. Most of the main sectors are sectors with relatively low labor absorption due to technological overcrowding. The ten main sectors contribute 59.85 percent to GRDP.

The 2016 value added structure shows changes in the ten main sectors that dominate the economic value creation of Jambi Province. The biggest contribution was given by the 
gas and geothermal oil sector, not much different from 2014 even though the cinnamon industry became one of the plantation crop sectors from ten sectors that compiled the jambi province's added value in 2016. Complete data on the output structure detailed according to the $\mathrm{IO}$ sector can be seen in the attachment.

Table 3 - Value Added Structure of Jambi Province Year 2014and 2016

\begin{tabular}{|c|l|c|c|}
\hline \multirow{2}{*}{ No } & \multicolumn{1}{|c|}{ Sector } & \multicolumn{2}{|c|}{ Contribution (\%) } \\
\cline { 3 - 4 } & & 2014 & 2016 \\
\hline 1 & (23) mining of oil, gas and geothermal energy & 12,18 & 12,82 \\
2 & (43) trade & 11,40 & 12,06 \\
3 & (55) social services & - & 4,42 \\
4 & (51) Bank and financial institutions & 7,21 & - \\
5 & (50) communication & - & 3,73 \\
6 & (42) Buildings & 5,32 & 6,97 \\
7 & (44) Hotels and restaurants & 5,07 & - \\
8 & (54) government and defense & 4,85 & 4,67 \\
9 & (10) rubber & 4,83 & 7,91 \\
10 & (24) non oil gas mining and excavation & - & 3,65 \\
11 & (14) cinnamon & - & 3,39 \\
12 & (53) property, real estate and company service & 3,79 & - \\
13 & (12) palm oil & 2,71 & 4,44 \\
14 & (45) land transportation & 2,49 & - \\
\hline & Sub Total & 59,85 & 64,06 \\
& Others & 40,15 & 35,94 \\
\hline
\end{tabular}

The intermediate demand that occurs in the process of creating output and the economic added value of Jmabi Province continues to change. This happens along with the increasingly advanced technology adoption process. Industrialization is a major factor in changes in demand between the primary sector and the service sector, Table 4.

Table 4 - Demand Structure Intermediate Jambi Province Year 2014and 2016

\begin{tabular}{|c|l|c|c|}
\hline \multirow{2}{*}{ No } & \multicolumn{1}{|c|}{ Sector } & \multicolumn{2}{|c|}{ Contribution (\%) } \\
\cline { 3 - 4 } & \multicolumn{1}{|c|}{2014} & 2016 \\
\hline 1 & (51) Bank and financial institutions & 12,12 & 13,52 \\
2 & (37) oil, gas and geothermal refining industry & 8,30 & 6,88 \\
3 & (10) rubber & 7,95 & 10,26 \\
4 & (53) rent, real estate and company service & 5,85 & 5,77 \\
5 & (43) trade & 4,83 & 4,68 \\
6 & (35) basic chemical industry & 4,66 & 4,75 \\
7 & (36) fertilizer industry & 4,25 & 6,62 \\
8 & (45) land transportation & 4,18 & 4,45 \\
9 & (39) metal goods, machinery and equipment industries & 3,84 & 3,58 \\
10 & (27) other food industries & 3,47 & 3,19 \\
\hline & Sub Total & 59,44 & 63,70 \\
& Others & 40,56 & 36,30 \\
\hline
\end{tabular}

Banks and financial institutions became the sector with the largest contribution to demand between 2014. The output and large added value of the trade sector made this sector the main catalyst of the production process. Sectors that produce raw materials and capital goods also contribute greatly to total demand between. 59.44 percent of the total demand was contributed by ten main sectors.

The increase in the value of rubber production in 2016 made it rise to the second position as the main sector in ten sectors that dominated demand between aggregate demand in 2016. Still in the range of 60 percent, ten major sectors in demand among more dominated by industry groups and trade and transportation margins. In the agricultural commodity group only the rubber sector is still able to become the main supplier of demand between. Banks and financial institutions contribute 13.52 percent and characterize the increasingly modren economy through financial support. Complete data on demand structure between those specified in the $1 \mathrm{O}$ sector can be seen in the appendix. 
The Input output model produces GRDP calculations in three approaches. Three quadrants in the framework of the respective IO model will produce a GRDP calculation approach. GRDP as intended consists of the GRDP above (production approach), (expenditure approach) and income approach (income approach).

GRDP according to business fields from the results of processing 10 Tables for 2007, 2014 and 2016 are grouped into 9 business sectors, Table 5.

Table 5 - GRDP Structure According to Field of Business Year 2007, 2014 and 2016

\begin{tabular}{|c|l|ccc|}
\hline \multirow{2}{*}{ No Sector / Business Field } & \multicolumn{3}{|c|}{ Contribution (\%) } \\
\cline { 3 - 5 } & \multicolumn{1}{|c|}{ Soriculture } & 14,96 & 2014 & 2016 \\
\hline 1 & Agriculture & 17,73 & 13,22 & 16,56 \\
2 & Mining and excavation & 23,48 & 13,03 & 10,40 \\
3 & Processing industry & 2,27 & 0,89 & 0,20 \\
4 & Electricity of Gas and Clean Water & 11,39 & 5,32 & 6,97 \\
5 & Building & 7,46 & 16,47 & 13,24 \\
6 & Trade, hotels and restaurants & 7,22 & 5,68 & 7,06 \\
7 & Transportation and Communication & 4,79 & 11,28 & 5,29 \\
8 & Finance, leasing and company services & 10,70 & 7,68 & 10,80 \\
9 & Services & & & \\
\hline
\end{tabular}

The role of the agricultural sector in the economy of Jambi Province until 2016 is still the largest and its contribution tends to increase. In contrast to other primary sectors, namely the mining and quarrying sector which tends to decline in its role to around 13 percent in 2014 and despite an increase in 2016. Secondary sectors in general did not seem to take over the transformation process, even the role tends to weaken. In the tertiary group, it can be seen that the financial, leasing and business services sector increasingly shows a role in accompanying fluctuating trade, hotel and restaurant sectors.

GRDP according to expenditure shows how the output created by an economy is used in the final demand, Table 6.

Table 6 - GRDP Structure According to year Expenditures 2007, 2014 and 2016

\begin{tabular}{|c|l|ccc|}
\hline \multirow{2}{*}{ No } & \multicolumn{1}{|c|}{ Sector / Business Field } & \multicolumn{3}{c|}{ Contribution (\%) } \\
\cline { 3 - 5 } & & 2007 & 2014 & 2016 \\
\hline 1 & Household Consumption Expenditures & 61,10 & 52,75 & 58,06 \\
2 & Governmental Private Expenditures & 13,30 & 9,75 & 12,35 \\
3 & Gross Fixed Capital Formation & 7,41 & 14,31 & 5,79 \\
4 & Changes in Inventory & 1,89 & 3,83 & 3,61 \\
5 & Export & 44,64 & 34,33 & 57,26 \\
6 & Import & 28,32 & 14,97 & 37,07 \\
\hline
\end{tabular}

Changes in the GRDP structure according to expenditures, among others, show a decrease in the role of household consumption and an increase in the contribution of net exports in macro equations. Mesih government consumption expenditure is relatively large and tends to increase, while the role of the investment component actually tends to decline. The increase in the net export component if linked to changes in the GRDP structure according to business reports indicates that the exported goods are not industrial goods but mining products and agricultural products in raw form.

Production factors used in the production process such as capital, labor, expertise / technology etc. enjoy the services that are aggregated in the GRDP value according to income. In the framework of the IO model the remuneration is grouped into components of wages / income, business surplus, depreciation and indirect taxes, Table 7. Components of wages / wages, business surpluses and indirect taxes increased in 2014 while depreciation experienced a decline. The share of the business surplus that reaches double the upag / gajih component shows that remuneration for production factors that are received by households as workers is relatively smaller than the remuneration received by employers. This will lead to inequality. If a business surplus is used for investment, it is expected to create employment opportunities and reduce income slack. 
Table 7 - GRDP structure according to year income 2007, 2014 and 2016

\begin{tabular}{|c|l|ccc|}
\hline \multirow{2}{*}{ No } & \multicolumn{1}{|c|}{ Sector / Business Field } & \multicolumn{3}{c|}{ Contribution (\%) } \\
\cline { 3 - 5 } & \multicolumn{1}{|c|}{2007} & 2014 & 2016 \\
\hline 1 & Wages / salaries & 33,30 & 30,52 & 31,33 \\
2 & Business Surplus & 59,65 & 62,29 & 61,52 \\
3 & Depreciation & 4,74 & 4,66 & 4,86 \\
4 & Indirect tax & 2,31 & 2,52 & 2,29 \\
\hline
\end{tabular}

Multiplier numbers are a measure of the response of a sector to the stimulation of changes in an economy which are usually expressed in a causal relationship. Some commonly known multiplier categories are Initial impacti, output multiplier, labor multiplier and income multiplier (multiplier income).

Type I output multiplier analysis with a Keynesian multiplier. If there is a change in the akgir demand variable, it can be seen how much influence the change has on the increase in output across sectors. The greater the multiplier value generated by a sector, it can be concluded that the sector has a close relationship with other sectors. Type II multiplier analysis illustrates the relationship between the increase in output of a sector with total output.

Table 8 - Sector with the Biggest Output Multiplier Year2007, 2014 and 2016

\begin{tabular}{|c|c|c|c|c|c|c|c|}
\hline \multirow{2}{*}{ No } & \multirow{2}{*}{ Sector } & \multicolumn{2}{|c|}{2007} & \multicolumn{2}{|c|}{2014} & \multicolumn{2}{|c|}{2016} \\
\hline & & Open & Close & Open & close & Open & close \\
\hline 1 & (10) Rubber & 1,76 & 1,94 & 1,74 & 1,89 & 1,75 & 1,92 \\
\hline 2 & (30) Sawmill and wood processing industry & 1,73 & 1,92 & 1,71 & 1,87 & 1,72 & 1,9 \\
\hline 3 & (40) Other goods industries & 1,72 & 1,89 & 1,7 & 1,85 & 1,71 & 1,87 \\
\hline 4 & (29) Textile industry, leather goods and footwear & 1,71 & 1,91 & 1,7 & 1,86 & 1,7 & 1,88 \\
\hline 5 & (32) Manufacture of building materials and wood furniture & 1,7 & 1,93 & 1,69 & 1,88 & 1,7 & 1,9 \\
\hline 6 & (21) Marine Fisheries & 1,68 & 1,86 & 1,68 & 1,86 & 1,68 & 1,83 \\
\hline 7 & (16) Domestic chicken and its results & 1,68 & 1,91 & 1,67 & 1,82 & 1,68 & 1,88 \\
\hline 8 & (31) Plywood industry and the like & 1,68 & 1,89 & 1,67 & 1,84 & 1,67 & 1,86 \\
\hline 9 & (44) Hotels and restaurants & 1,65 & 1,87 & 1,64 & 1,82 & 1,65 & 1,84 \\
\hline 10 & (46) Sea transportation & 1,64 & 1,78 & 1,64 & 1,75 & 1,64 & 1,76 \\
\hline
\end{tabular}

Table 8 presents ten sectors with the largest number of output multipliers for 2007, where most sectors were manufacturing industries. Industries with the largest number of output multipliers are dominated by industrial groups that process agricultural products and industries providing agricultural production facilities.

In 2014 a number of primary sectors had multiplier numbers which were included in the top ten sectors of multiplier output, including the rubber sector, marine fisheries and domestic chicken and their results. The number of multipliers in 2014 is relatively smaller than in 2007.

The biggest output multiplier from the results of the 2014 IO table processing is relatively not different from 2016 . The difference is seen in the quantity of output multiplier values of each sector which is slightly larger than the previous period. This confirms the absence of the creation of superior sectors in Jambi's economy.

An income multiplier analysis is an analytical tool to see the effect of changes in the final demand in a sector on income in the sector due to the economy. In other words, the income multiplier number value indicates the total total household income created due to the addition of a final demand unit. This effect is often referred to as household income multiplier, Table 9.

Several primary sectors in 2007 were included in ten sectors which had the highest multiplier numbers, including the palm oil, rubber, marine fisheries, other fisheries and freerange sectors and their results. The diversity of income multiplier numbers also looks smaller, in line with the output multiplier numbers. The only tertiary sector included in the first sector with the largest multiplier number of 2007 is the sea transportation sector. The biggest multiplier value from the results of the $2014 \mathrm{IO}$ table processing is relatively no different from 2016. This indicates that there is no sector that promises income above the average of other sectors in the economy of Jambi Province. 
Table 9 - Sectors with the Biggest Income Multiplier Year 2007, 2014 and 2016

\begin{tabular}{|c|l|cc|cc|cc|}
\hline \multirow{2}{*}{ No Sector } & \multicolumn{2}{|c|}{2007} & \multicolumn{2}{c|}{2014} & \multicolumn{2}{c|}{2016} \\
\cline { 3 - 7 } & & $\begin{array}{c}\text { Type } \\
1\end{array}$ & $\begin{array}{c}\text { Type } \\
I\end{array}$ & $\begin{array}{c}\text { Type } \\
I\end{array}$ & $\begin{array}{c}\text { Type } \\
I I\end{array}$ & $\begin{array}{c}\text { Type } \\
I\end{array}$ & $\begin{array}{c}\text { Type } \\
I I\end{array}$ \\
\hline 1 & (12) Palm Oil & 2,99 & 3,52 & 2,99 & 3,40 & 3,00 & 3,46 \\
2 & (40) Other goods industries & 2,63 & 3,10 & 2,64 & 3,00 & 2,63 & 3,03 \\
3 & (28) Beverage Industry & 2,62 & 3,09 & 2,63 & 2,99 & 2,62 & 3,02 \\
4 & (46) Sea transportation & 2,35 & 2,76 & 2,35 & 2,67 & 2,35 & 2,71 \\
5 & (30) Sawmill and wood processing industry & 2,34 & 2,75 & 2,34 & 2,66 & 2,34 & 2,70 \\
6 & (10) Rubber & 2,25 & 2,64 & 2,25 & 2,56 & 2,24 & 2,59 \\
7 & (21) Marine fisheries & 2,09 & 2,46 & 2,09 & 2,38 & 2,08 & 2,41 \\
8 & (22) Other fisheries & 2,05 & 2,42 & 2,06 & 2,34 & 2,06 & 2,37 \\
9 & (16) Domestic chicken and its results & 2,05 & 2,42 & 2,05 & 2,34 & 2,05 & 2,37 \\
10 & (32) Manufacture of building materials and wooden & 2,02 & 2,38 & 2,03 & 2,30 & 2,02 & 2,33 \\
& furniture & 2,02 & \\
\hline
\end{tabular}

The linkages between sectors in the framework of IO consist of backward linkage and forward linkage. The linkages between sectors will have an impact on the degree of sensitivity and crossing power of a sector to other sectors. Information about the relationship between sectors that occur in an economy is obtained from the input multiplier value matrix input coefficient produced by the input output table.

Backward linkage analysis can be divided into direct linkages and total backward linkages. Measuring the index of intercourse is not enough because it does not reflect the diversity of multiple influences between sectors. A sector is said to be the superior sector must have a high linkage and a low spread index, Table 10.

Table 10 - Sector with the Largest Backward Relationship Index for the Year 2007, 2014 and 2016

\begin{tabular}{|c|c|c|c|c|c|c|c|}
\hline \multirow[b]{2}{*}{ No } & \multirow{2}{*}{ Sector } & \multicolumn{2}{|c|}{2007} & \multicolumn{2}{|c|}{2014} & \multicolumn{2}{|c|}{2016} \\
\hline & & Totaly & Index & Totaly & Index & Totaly & Index \\
\hline 1 & (10) Rubber & 1,24 & 1,01 & 1,25 & 1,00 & 1,24 & 1,00 \\
\hline 2 & (30) Sawmill and wood processing industry & 1,22 & 0,89 & 1,22 & 0,88 & 1,22 & 0,89 \\
\hline 3 & (40) Other goods industries & 1,21 & 0,81 & 1,22 & 0,81 & 1,21 & 0,81 \\
\hline 4 & (29) Textile industry, leather goods and footwear & 1,21 & 1,03 & 1,22 & 1,03 & 1,21 & 1,03 \\
\hline 5 & $\begin{array}{l}\text { (32) Manufacture of building materials and wood } \\
\text { furniture }\end{array}$ & 1,20 & 0,77 & 1,21 & 0,77 & 1,20 & 0,77 \\
\hline 6 & (21) Marine Fisheries & 1,19 & 0,83 & 1,20 & 0,82 & 1,19 & 0,83 \\
\hline 7 & (16) Domestic chicken and its results & 1,19 & 0,83 & 1,20 & 0,82 & 1,19 & 0,83 \\
\hline 8 & (31) Plywood industry and the like & 1,18 & 0,88 & 1,19 & 0,87 & 1,18 & 0,87 \\
\hline 9 & (44) Hotels and restaurants & 1,17 & 0,81 & 1,18 & 0,80 & 1,17 & 0,81 \\
\hline 10 & (46) Sea transportation & 1,16 & 0,83 & 1,17 & 0,82 & 1,16 & 0,83 \\
\hline
\end{tabular}

The IO table for 2007 shows a change in the main sector with the largest backward linkage figure, where the rubber sector is the sector with the greatest value. The diversity of backward relations figures in general seems to be smaller in variability and reflects the absence of a leading sector which is a barometer in the economy. This condition is relatively the same as in 2016, only a slight increase in the value of the backward linkages for each sector.

In 2016, the fisheries sector declined and was one level below the livestock sector, namely the domestic chicken sector and its results. While other sectors are still in the same position, only the total value and index are different.

The future linkages of other sectors in the economy of Jambi Province in 2007 have a value of less than 2. Banks and financial institutions are other tertiary sectors in addition to the trade sector which is included in the top ten largest forward linkages. Electricity and drinking water with forward linkages show that the role of the utility sector has an impact on other sectors in the economy, Table 11.

There were no fundamental differences between 2014 and 2016 when viewed from the forward linkages. Ten sectors that have the highest linkages are the same as the conditions 
in the previous period. The highest linkages in 2014 are still owned by the oil, gas and geothermal refining industry.

Table 11 - Sector with the Future Linkage Index Largest year 2007, 2014, and 2016

\begin{tabular}{|c|c|c|c|c|c|c|c|}
\hline \multirow{2}{*}{ No } & \multirow{2}{*}{ Sector } & \multicolumn{2}{|c|}{2007} & \multicolumn{2}{|c|}{2014} & \multicolumn{2}{|c|}{2016} \\
\hline & & Totaly & Index & Totaly & Index & Totaly & Index \\
\hline 1 & (37) Oil, gas and geothermal refining industry & 2,19 & 0,43 & 2,17 & 0,43 & 2,19 & 0,43 \\
\hline 2 & (51) Banks and financial institutions & 1,83 & 0,54 & 1,68 & 0,55 & 1,83 & 0,54 \\
\hline 3 & (27) Other food industries & 1,6 & 0,62 & 1,6 & 0,63 & 1,6 & 0,62 \\
\hline 4 & (23) Mining of oil, gas and geothermal energy & 1,52 & 0,61 & 1,52 & 0,62 & 1,52 & 0,61 \\
\hline 5 & (43) Trade & 1,51 & 0,58 & 1,51 & 0,59 & 1,51 & 0,58 \\
\hline 6 & (39) Metal industry, machinery and equipment & 1,51 & 0,6 & 1,5 & 0,61 & 1,51 & 0,6 \\
\hline 7 & (40) Other new industries & 1,44 & 0,65 & 1,41 & 0,67 & 1,44 & 0,65 \\
\hline 8 & (35) Basic chemical industry & 1,37 & 0,67 & 1,33 & 0,68 & 1,36 & 0,67 \\
\hline 9 & (41) Electricity and drinking water & 1,34 & 0,76 & 1,3 & 0,69 & 1,34 & 0,76 \\
\hline 10 & (36) Fertilizer Industry & 1,28 & 0,69 & 1,3 & 0,79 & 1,28 & 0,69 \\
\hline
\end{tabular}

Changes in the position of the top 10 sectors have the largest future linkage index in 2016 only in the electricity and drinking water sector (41) which is superior to one position above the fertilizer industry (36).

Sectors that have strong links both backward and forward are referred to as key sectors in the economy. Some sectors that have become key sectors in the economy of Jambi Province throughout the period of observation include the other food industry sectors, industries of rubber and plastic goods, electricity and drinking water, and the land transportation sector. These sectors are key sectors in 2007, 2014 and 2016, Table 12.

Table 12 - Key Sectors of the Economy of Jambi Province in the year 2007, 2014, 2016

\begin{tabular}{|l|ccc|}
\hline \multicolumn{1}{|c|}{ Sector Name } & \multicolumn{3}{c|}{ Key Sector } \\
\cline { 2 - 4 } (27) Other food industries & 2007 & 2014 & 2016 \\
(33) Manufacture of rubber and plastic goods & $\sqrt{ }$ & $\sqrt{ }$ & $\sqrt{ }$ \\
(34) Manufacture of paper and paper products & $\sqrt{ }$ & - & - \\
(36) Fertilizer industry & $\sqrt{ }$ & - & - \\
(37) Oil, gas and earth milling industry & - & $\sqrt{ }$ & $\sqrt{ }$ \\
(39) Manufacture of metal goods, machinery \& equipment & $\sqrt{ }$ & - \\
(40) Other goods industries & - & $\sqrt{ }$ & - \\
(41) Electricity and drinking water & $\sqrt{ }$ \\
(43) Trade & $-\sqrt{ }$ & $\sqrt{ }$ \\
(45) Land transportation & $\sqrt{ }$ & $\sqrt{ }$ \\
(49) Transportation support services & - & $\sqrt{ }$ & $\sqrt{ }$ \\
\end{tabular}

The paper and paper products industry sector, the fertilizer industry sector and the metal goods, machinery and equipment industry sectors were sectors that were key sectors in 1998 but were no longer the key sectors in the following period. Meanwhile, there were four other sectors which were key sectors in 2007 and 2014, although not a key sector in the previous year. The four sectors are the industrial sector of oil, gas and earth milling, other goods industries, trade and transportation support services.

\section{CONCLUSION AND RECOMMENDATIONS}

The discussion of the findings of the observations according to the research method produces several conclusions including:

- There has been a change in the structure of demand between and demand in the economy of Jambi Province in line with economic growth in the period 2007 to 2016;

- The role of the agricultural sector in the economy of the Jambi region significantly changes the style of the economy from the dominance of the primary sector to tertiary sectors and shows symptoms of deindustrialization; 
- The economic sector that has high inter-sectoral linkages and is key in the economy of Jambi Province during the period of observation includes other food industry sectors, rubber and plastic, electricity and drinking water as well as land transportation industries.

Some things that need to be suggested are the transformation process of Jambi Province, including:

- Strengthening the industrial sector that utilizes primary sector production output to prevent too rapid de-industrialization and make it an engine of growth. Reducing dependence on non-renewable natural resources (sustainable resources) for sustainable development;

- The creation of added value is prioritized in the largest labor absorbing sector, and the biggest income multiplier is that there is no income imbalance in the community;

- Creation of a healthy investment climate to ensure the rotation of the domestic economy and reduce capital outflows.

\section{REFERENCES}

1. Badan Pusat Statistik (BPS). (2007, 2014, 2016). Tabel Input-Output Provinsi Jambi Tahun 2017. Provinsi Jambi, Jambi.

2. Firmansyah. 2006. Operasi Matrix Dan Analisis Input-Output (I-O) Untuk Ekonomi Aplikasi Praktis Dengan Microsoft Excel Dan Matlab. LSKE FE UNDIP, Badan Penerbit Universitas Diponegoro, Semarang.

3. Kuncoro, Mudrajad. 1997. Ekonomi Pembangunan: Teori, Masalah, dan Kebijakan. Edisi Pertama. UPP AMP YPKN. Yogyakarta.

4. Mauludin, Dudi. 2008. Dampak Kebijakan Fiskal Terhadap Pertumbuhan Ekonomi dan Tingkat Kesempatan Kerja (Suatu Kajian Input-Input Atas Pengeluaran Pemerintah Provinsi Jawa Tengah Tahun 2006). Skripsi S1 (Tidak Dipublikasikan) FE UNDIP: Semarang.

5. Nazara, suahasil. 1997. Analisis Input-Output. Lembaga Penerbit Fakultas Ekonomi Unversitas Indonesia. Jakarta.

6. Ropingi dan Artanto, Dani. 2002. Peranan Sektor Pertanian Dalam Pengembangan Perekonomian Wilayah Propinsi Jawa Tengah (Pendekatan Analisis Input-Ouput). Jurnal Ekonomi Pembangunan Vol. 3 No. 2.

7. Suharno. 1999. Analisis Input Output Industri Manufaktur di Jawa Tengah. Media Ekonomi dan ManajemenVol. 19.

8. Suhendra, Susy. 2004. Peranan Sektor Pertanian Dalam Pertumbuhan Ekonomi Di Indonesia Dengan Pendekatan Input-Output. Jurnal Ekonomi dan Bisnis No. 2 Jilid 9 2004. Universitas Gunadarma. Depok. 